\title{
Pelvis Cancer pT2 TNM Finding v8
}

National Cancer Institute

\section{Source}

National Cancer Institute. Pelvis Cancer pT2 TNM Finding v8. NCI Thesaurus. Code C136597.

Pelvis cancer with tumor confined to one pelvic segment with extraosseous extension or two segments without extraosseous extension. (from AJCC 8th Ed.) 